\title{
Analisis Kinerja Usaha Kecil dan Menengah Pengolahan Hasil Perikanan di Kabupaten Situbondo Pada Masa Pandemi Covid-19
}

\author{
Ramli \\ Universitas Ibrahimy \\ ramliarul80@gmail.com
}

\begin{abstract}
The impact of the Covid-19 pandemic also has an impact on the business of fisheries result processing in the form of a decrease in demand for fish and processed products both in the domestic and foreign markets. This causes an oversupply of fish catch which causes fish prices to decline, thus affecting the economy of fishermen and fish processing entrepreneurs. The policy of a Large-Scale Social Enforcement as a step to stop the spread of Covid-19 also slows the flow of distribution of fish and fish processing products. The purpose of this study was to analyze the performance of small and medium business of fisheries result processing in Situbondo district during the covid-19 pandemic. The research method used in this research is Impotrance Performance Analysis (IPA). The results of this study indicate that the Covid-19 pandemic has had implications for the decline in the performance of small and medium business of fisheries result processing in Situbondo district with the influencing variables are the availability of raw materials (1), labor productivity (4), the product quantity produced (10) and market demand (12). The decline in these performance variables has an impact on the inability of small and medium business of fisheries result processing to maintain a balance between supply and demand. The strategy to improve the performance of small and medium business of fisheries result processing during the Covid-19 pandemic is to good management implement of supply and demand by controlling of production and markets that are also good.
\end{abstract}

keywords: performance, fisheries result processing, impotrance performance analysis

Abstrak 


\section{Jurnal DinamikA}

Volume 2 No. 2 (2021)

E-ISSN: 2723-1410

Website: https://jurnal.iainsalatiga.ac.id/index.php/dinamika/index

Dampak Pandemi Covid-19 juga berdampak pada usaha pengolahan hasil perikanan berupa penurunan permintaan atas ikan dan produk olahannya baik di pasar domestik maupun luar negeri. Hal ini menyebabkan over supply tangkapan ikan yang menyebabkan harga ikan menurun sehingga mempengaruhi perekonomian nelayan dan pengusaha pengolahan ikan. Adanya kebijakan Pemberlakuan Sosial Berskala Besar (PSBB ) sebagai langkah untuk menghentikan penyebaran Covid-19 juga memperlambat arus distribusi ikan dan produk pengolahan ikan. Tujuan penelitian ini adalah untuk menganalisis kinerja UKM pengolahan hasil perikanan di kabupaten situbondo pada masa pandemi covid-19. Metode penelitian yang digunakan dalam penelitian ini adalah Impotrance Performance Analysis (IPA). Hasil penelitian menunjukkan ini menunjukkan bahwa Pandemi Covid-19 telah memberikan implikasi pada menurunnya kinerja UKM pengolahan hasil perikanan di Kabupaten situbondo dengan variabel-variabel yang mempengaruhinya adalah ketersediaan bahan baku (1), produktivitas tenaga kerja (4), kuantitas produk yang dihasilkan (10) dan permintaan pasar (12). Menurunnya kinerja variabel-variabel tersebut berdampak pada ketidak mampuan UKM pengolahan hasil perikanan menjaga keseimbangan antara persediaan dengan. Strategi meningkatkan kinerja UKM pengolahan hasil perikanan pada masa Pnademi Covid-19 adalah menerapkan manajemen persediaan dan permintaan yang baik dengan melakukan pengendalian produksi dan pasar yang juga baik.

kata kunci : kinerja, pengolahan hasil perikanan, impotrance performance analysis

\section{PENDAHULUAN}

Pandemi COVID-19 telah memberikan dampak pada Usaha Kecil dan Menengah (UKM) di Indonesia, berdasarkan data dari Kementerian Koperasi yang menggambarkan bahwa 1.163 .713 pelaku UKM terdampak pandemi virus corona (Covid-19). Kebanyakan UKM yang terkena dampak Covid-19 bergerak pada bidang kebutuhan sehari-hari, sedangkan sektor UKM yang paling terdampak yakni makanan dan minuman (Amri, 2020). UKM pengolahan hasil perikanan yang merupakan bagian dari sektor makanan tentunya juga terdampak pandemi covid-19, kebijakan Pemerintah sebagai langkah untuk menghentikan penyebaran Covid-19 telah memperlambat arus distribusi ikan dan produk pengolahan ikan (Kumala, et.al, 2021).

Pandemi covid-19 telah merusak rantai pasokan, penurunan kapasitas produksi, penutupan pabrik, hingga larangan bepergian. Industri yang terdampak di era pandemi covid-19 meliputi sektor manufaktur, transportasi, pariwisata. 
Jurnal DinamikA

Volume 2 No. 2 (2021)

E-ISSN: $2723-1410$

Website: https://jurnal.iainsalatiga.ac.id/index.php/dinamika/index

Sementara Industri yang mampu bertahan ditengah pandemi covid-19 adalah industtri yang terkait dengan pemenuhan kebutuhan dasar meliputi Listik, air bersih, pertanian, peternakan, perkebunan, perikanan, otomotif dan perbankan. Demikian halnya dengan industri ritel yang mampu bertahan, hal ini dikarenakan sebagian memanfaatkan penjualan melalui marketing digital. Perlu strategi berbagai pihak untuk membangkitkan UKM agar bisa survive ditengah pandemi covid-19 ini dan berusaha kembali stabil (Rosita, 2020).

Pandemi covid-19 juga berdampak pada kinerja usaha sektor perikanan, seperti pada budidaya ikan, dalam hal ini pendapatan para pembudidaya ikan yang menurun. Penurunan harga ikan sebesar 15,79\% (Rp 3.000) dari harga normal saat sebelum Pandemi Covid-19 telah menyebabkan kerugian yang besar dan secara langsung kepada bagi para pembudidaya ikan. Ada pilihan untuk tidak melepas (menjual) ikan saat ini, namun tetap saja para pembudidaya akan menanggung kerugian berupa peningkatan biaya produksi karena bertambahnya biaya pakan yang harus ditanggung. Selain itu, belum adanya kejelasan kapan berakhirnya Pandemi Covid-19 ini telah memperburuk dampaknya bagi para pembudidaya ikan dan usaha terkait lainnya (Wahidin, et.al., 2020). Pandemi Covid-19 juga berpengaruh pada kinerja usaha penangkapan ikan, nelayan mengurangi aktivitas tangkap ikan. Dampak Pandemi Covid-19 juga berdampak pada usaha pengolahan hasil perikanan berupa penurunan permintaan atas ikan dan produk olahannya baik di pasar domestik maupun luar negeri. Hal ini menyebabkan over supply tangkapan ikan yang menyebabkan harga ikan menurun sehingga mempengaruhi perekonomian nelayan dan pengusaha pengolahan ikan. Adanya kebijakan Pemberlakuan Sosial Berskala Besar (PSBB ) sebagai langkah untuk menghentikan penyebaran Covid-19 juga memperlambat arus distribusi ikan dan produk pengolahan ikan (Kumala, et.al., 2021)

Berdasarkan uraian diatas, maka tujuan penelitian ini adalah untuk menganalisis kinerja UKM pengolahan hasil perikanan di kabupaten situbondo pada masa pandemi covid-19.

\section{METODE PENELITIAN}


Jurnal DinamikA

Volume 2 No. 2 (2021)

E-ISSN: $2723-1410$

Website: https://jurnal.iainsalatiga.ac.id/index.php/dinamika/index

Penelitian dilaksanakan di Kabuapten Situbondo Jawa Timur dengan melibatkan 20 (dua puluh) UKM Pengolahan Hasil Perikanan sebagai responden. Metode penelitian yang digunakan dalam penelitian ini adalah Impotrance Performance Analysis (IPA). Analisis ini mengukur gap antara tingkat kondisi (X) dan tingkat kepentingan $(\mathrm{Y})$ variabel-variabel usaha pengolahan hasil perikanan. Analisis ini mengukur kesenjangan antara tingkat kondisi saat ini dan tingkat kepentingan variabel-variabel usaha pengolahan hasil perikanan (Algifari, 2016). Variabel yang digunakan dalam penelitian ini adalah

Tabel 1. Indikator, Variabel, dan Definisi Operasional

\begin{tabular}{ll}
\hline \multicolumn{1}{c}{ Indikator/Variabel } & \multicolumn{1}{c}{ Definisi Operasional } \\
\hline Bahan Baku & \\
1. Ketersediaan bahan baku & Kontinuitas bahan baku sebagai \\
2. Harga bahan baku & input produksi Tingkat Harga bahan \\
3. Kualitas bahan baku & baku. \\
& Tingkat kualitas bahan baku produksi \\
\hline
\end{tabular}

Tenaga Kerja

4. Produktivitas tenaga kerja

Tingkat kemampuan tenaga kerja dalam menghasilkan produk

5. Jumlah tenaga kerja

Tingkat pemenuhan jumlah tenaga

6. Keterampilan tenaga kerja kerja yang tersedia dalam kegiatan usaha

Kualitas tenaga kerja yang tersedia berdasarkan keterampilan dan atau tingkat pendidikan.

Permodalan

7. Ketersediaan modal

8. Akses permodalan
Ketersediaan modal untuk menjalankan industri baikdari diri sendiri atau pihak luar. Kemudahan dalam memperoleh modal dalam bentuk apapun yang mempengaruhi produksi.

Produksi

9. Kapasitas produksi

10. kuantitas produk yang dihasilkan hasil produksi maksimum yang dapat diproduksi atau dihasilkan dalam satuan waktu tertentu 
Jurnal DinamikA

Volume 2 No. 2 (2021)

E-ISSN: $2723-1410$

Website: https://jurnal.iainsalatiga.ac.id/index.php/dinamika/index

11. Kualitas produk yang dihasilkan Tingkat perbandingan antara kapasitas maksimum dengan kapasitas produk yang dihasilkan. Tingkat kualitas produk dapat diukur dari banyak atau tiadknya produk return.

Pemasaran

12. Permintaan pasar

13. Aksesibilitas distribusi

Tingkat kebutuhan pasar terhadap produk

14. Jaringan pemasaran

Aksesibilitas distribusi Aksesibilitas/ tingkat kondisi jalan jalur distribusi produk

Tingkat jejaring pemasaran yang dimiliki

Teknologi

15. Penggunaan teknologi untuk Tingkat penggunaan/ ketersediaan produksi teknologi untuk produksi

16. Akses dalam memperoleh teknologi untuk produksi

Tingkat akses dalam memperoleh teknologi untuk produksi

17. Penggunaan teknologi dalam Tingkat penggunaan/ ketersediaan pemasaran teknologi dalam pemasaran

18. Akses dalam memperoleh teknologi untuk pemasaran Tingkat akses dalam memperoleh teknologi untuk pemasaran

Manajemen

19. Perencanaan pengembangan usaha

Ada tidaknya perencanaan usaha berupa dokumen rencana, atau strategi-strategi detail yang ingin

20. Pembukuan usaha dicapai usaha Ada atau tidaknya laporan

21. Kondisi lokasi usaha pembukuan keuangan.

22. Kegiatan evaluasi usaha Tingkat kondisi usaha, tata letak ruangan produksi Ada tidaknya kegiatan evaluasi dan penilaian kinerja usaha salam periode tertentu

Kelembagaan

23. Peran kelompok pengusaha

24. Peran pemerintah

Ada tidaknya peran kelompok pengusaha dalam pengembangan usaha.

25. Legalitas usaha/Jaminan mutu Ada tidaknya peran pemerintah lokal produk

26. Networking atau daerah dalam pengembangan usaha. 


\begin{tabular}{ll}
\hline & $\begin{array}{l}\text { Ada tidaknya dokumen legalitas } \\
\text { usaha seprti SIUP, TDP, atau SKU, } \\
\text { PIRT dan Sertifikat Halal } \\
\text { Ada tidaknya Jaringan kelembagaan } \\
\text { atau kerjasama dengan lembaga } \\
\text { lainnya }\end{array}$ \\
& $\begin{array}{l}\text { Keberanian mengambil risiko dan } \\
\text { Kewirausahaan }\end{array}$ \\
$\begin{array}{l}\text { 27. Keberanian mengambil resiko } \\
\text { Inovatif dalam pengambilan } \\
\text { kebijakan }\end{array}$ & $\begin{array}{l}\text { setiap kebijakan yang dikeluarkan } \\
\text { pada prinsipnya harus memuat } \\
\text { sesuatu yang baru }\end{array}$ \\
\hline
\end{tabular}

Sumber : data primer yang diolah, 2021

Penentuan tingkat kepentingan dilakukan dengan memberikan penilaian angka 1 sampai 4 pada setiap variabel. Adapun tingkat nilai serta bobot penilaiannya adalah sebagai berikut:

1. Bobot 4 untuk jawaban sangat penting.

2. Bobot 3 untuk jawaban penting.

3. Bobot 2 untuk jawaban kurang penting.

4. Bobot 1 untuk jawaban tidak penting.

Sedangkan penilaian tingkat kondisi saat ini juga berdasarkan 4 tingkatan nilai dengan pembobotan sebagai berikut:

1. Bobot 4 untuk jawaban sangat baik.

2. Bobot 3 untuk jawaban baik.

3. Bobot 2 untuk jawaban kurang baik.

4. Bobot 1 untuk jawaban buruk.

Pemilihan sample dilakukan dengan teknik probability sampling dengan metode stratified random sampling berdasaran skala usaha, yaitu kecil dan menengah. Uji validitas dilakukan dengan untuk menguji pertanyaan kuesioner dapat dimengerti oleh responden. Ukuran validitas dilihat dari nilai $r$ hitung $>r$ tabel, $\mathrm{r}$ tabel yang digunakan adalah 0,444 dengan $\mathrm{a}=0,05$. Uji realibilitas dilakukan untuk menguji apakah kuesioner dapat dipercaya sebagai instrumen pengumpul data. Realibilitas dilihat dari nilai Cronbach Alpha $>0,60$. Pengujian 
Jurnal DinamikA

Volume 2 No. 2 (2021)

E-ISSN: $2723-1410$

Website: https://jurnal.iainsalatiga.ac.id/index.php/dinamika/index

ini dilakukan dengan alat analisis software SPSS 24. Sedangkan strategi pengembangan UKM pengolahan hasil perikanan dirumuskan dengan menggunakan analisis deskriptif hasil wawancara.

\section{HASIL DAN PEMBAHASAN}

\section{a. Uji Validitas dan Reabilitas}

Uji validitas dan reliabilitas dikakukan sebelum analisis data dilakukan. Hal ini bertujuan untuk menguji instrumen yang akan digunakan. Hasil uji validitas terhadap variabel-variabel penelitian dalam aspek bahan baku, tenaga kerja, permodalan, produksi, pemasaran, teknologi, manajeman, kelembagaan dan kewirausahaan dapat dilihat pada Tabel 2.

Tabel 2. Hasil uji validitas

\begin{tabular}{lccc}
\hline \multicolumn{1}{c}{ Indikator/Variabel } & $\begin{array}{c}\text { r'hitung } \\
\text { Y }\end{array}$ & $\begin{array}{c}\text { r'hitung } \\
\text { X }\end{array}$ & Keterangan \\
\hline $\begin{array}{l}\text { Bahan Baku } \\
\text { 1. Ketersediaan bahan } \\
\text { baku }\end{array}$ & 0,61 & 0,75 & Valid \\
$\begin{array}{l}\text { 2. Harga bahan baku } \\
\text { 3. Kualitas bahan } \\
\text { baku }\end{array}$ & 0,59 & 0,86 & Valid \\
$\begin{array}{l}\text { Tenaga Kerja } \\
\text { 4. Produktivitas }\end{array}$ & 0,57 & 0,64 & Valid \\
$\quad$ tenaga kerja & 0,60 & & \\
$\begin{array}{l}\text { 5. Jumlah tenaga kerja } \\
\text { 6. Keterampilan } \\
\text { tenaga kerja }\end{array}$ & 0,49 & 0,92 & Valid \\
\hline $\begin{array}{l}\text { Permodalan } \\
\text { 7. Ketersediaan modal } \\
\text { 8. Akses permodalan }\end{array}$ & 0,56 & 0,83 & Valid \\
\hline $\begin{array}{l}\text { Produksi } \\
\text { 9. Kapasitas }\end{array}$ & 0,40 & & Valid \\
$\begin{array}{l}\text { produksi } \\
\text { 10. kuantitas produk } \\
\quad \text { yang dihasilkan }\end{array}$ & 0,47 & 0,80 & Valid \\
$\begin{array}{l}\text { 11. Kualitas produk } \\
\text { yang dihasilkan }\end{array}$ & 0,65 & 0,74 & Valid \\
\hline $\begin{array}{l}\text { Pemasaran } \\
\text { 12. Permintaan pasar }\end{array}$ & 0,54 & 0,69 & Valid \\
\hline
\end{tabular}


Jurnal DinamikA

Volume 2 No. 2 (2021)

E-ISSN: $2723-1410$

Website: https://jurnal.iainsalatiga.ac.id/index.php/dinamika/index

\begin{tabular}{|c|c|c|c|}
\hline $\begin{array}{l}\text { 13. Aksesibilitas } \\
\text { distribusi } \\
\text { 14. Jaringan } \\
\text { pemasaran }\end{array}$ & 0,49 & 0,62 & Valid \\
\hline \multicolumn{4}{|l|}{ Teknologi } \\
\hline $\begin{array}{l}\text { 15. Penggunaan } \\
\text { teknologi untuk } \\
\text { produksi }\end{array}$ & 0,46 & 0,85 & Valid \\
\hline $\begin{array}{l}\text { 16. Akses dalam } \\
\text { memperoleh } \\
\text { teknologi untuk } \\
\text { produksi }\end{array}$ & 0,57 & 0,83 & Valid \\
\hline $\begin{array}{l}\text { 17. Penggunaan } \\
\text { teknologi dalam } \\
\text { pemasaran }\end{array}$ & 0,57 & 0,85 & Valid \\
\hline $\begin{array}{l}\text { 18. Akses dalam } \\
\text { memperoleh } \\
\text { teknologi untuk } \\
\text { pemasaran }\end{array}$ & 0,57 & 0,66 & Valid \\
\hline \multicolumn{4}{|l|}{ Manajemen } \\
\hline $\begin{array}{l}\text { 19. Perencanaan } \\
\text { pengembangan } \\
\text { usaha }\end{array}$ & 0,54 & 0,72 & Valid \\
\hline 20. Pembukuan usaha & 0,51 & 0,66 & Valid \\
\hline $\begin{array}{l}\text { 21. Kondisi lokasi } \\
\text { usaha }\end{array}$ & 0,71 & 0,72 & Valid \\
\hline $\begin{array}{l}\text { 22. Kegiatan evaluasi } \\
\text { usaha }\end{array}$ & 0,49 & 0,66 & Valid \\
\hline \multicolumn{4}{|l|}{ Kelembagaan } \\
\hline $\begin{array}{l}\text { 23. Peran kelompok } \\
\text { pengusaha }\end{array}$ & 0,67 & 0,67 & Valid \\
\hline 24. Peran pemerintah & 0,54 & 0,92 & Valid \\
\hline $\begin{array}{l}\text { 25. Legalitas } \\
\text { usaha/Jaminan } \\
\text { mutu produk }\end{array}$ & 0,56 & 0,57 & Valid \\
\hline 26. Networking & 0,82 & 0,73 & Valid \\
\hline \multicolumn{4}{|l|}{ Kewirausahaan } \\
\hline $\begin{array}{l}\text { 27. Keberanian } \\
\text { mengambil resiko }\end{array}$ & 0,72 & 0,85 & Valid \\
\hline $\begin{array}{l}\text { 28. Inovatif dalam } \\
\text { pengambilan } \\
\text { kebijakan }\end{array}$ & 0,52 & 0,84 & Valid \\
\hline
\end{tabular}

Sumber : data primer yang diolah, 2021 
Hasil uji validitas menunjukkan bahwa nilai $r$ hitung setiap variabel lebih besar dari nilai $\mathrm{r}$ tabel. Hal ini menunjukkan bahwa variabel-variabel yang digunakan dalam analisis ini valid dan dapat digunakan untuk perhitungan analisis IPA. Sedangkan uji realibilitas dengan menggunakan Cronbach Alpa 0,60 menunjukkan bahwa hubungan antar variabel didalam indikator reliabel. Data tersebut dapat dilihat pada Tabel 3.

Tabel 3. Uji reliablitas

\begin{tabular}{lcc}
\hline \multicolumn{1}{c}{ Indikator/Variabel } & Cronbach's Alpha & Cronbach's Alpha \\
\hline 1. Bahan baku & Y & 0,79 \\
2. Tenaga kerja & 0,86 & 0,85 \\
3. Permodalan & 0,87 & 0,75 \\
4. Produksi & 0,71 & 0,81 \\
5. Pemasaran & 0,76 & 0,85 \\
6. Teknologi & 0,98 & 0,86 \\
7. Manajemen & 0,87 & 0,80 \\
8. Kelembagaan & 0,77 & 0,88 \\
9. Kewirausahaan & 0,86 & 0,79 \\
\hline
\end{tabular}

Sumber : data primer yang diolah, 2021

\section{b. Analisis Tingkat Kinerja Usaha Kecil dan Menengah Pengolahan Hasil}

\section{Perikanan}

Hasil penilaian setiap variabel memberikan informasi tindakan yang perlu dilakukan untuk mengatasi permasalahan yang dihadapi UKM pengolahan hasil perikanan. Adapun hasil penilaian tingkat kinerja UKM pengolahan hasil perikanan di Kabupaten Situbondo dapat dilihat pada Tabel 4. Variabel dengan tingkat kepentingan tertinggi adalah ketersediaan bahan baku, produktivitas tenaga kerja dan permintaan pasar dengan nilai 3,55. Ketersediaan bahan baku dinilai sangat penting karena proses produksi sangat bergantung pada bahan baku. Ketersediaan bahan baku sangat mempengaruhi keberlanjutan usaha (Martha \& Febriyantoro, 2019). Chen, et.al., (2006) menyebutkan bahwa produktivitas tenaga kerja adalah salah satu faktor yang mempengaruhi kemampuan menghasilkan output produksi. 
Sutrisno (2014) menyatakan bahwa permintaan pasar merupakan kemauan konsumen untuk membeli barang dan kemampuan konsumen untuk membayar. Permintaan pasar yang tinggi akan berdampak pada peningkatan volume produksi.

Variabel dengan tingkat kepentingan rendah adalah kondisi lokasi usaha dengan nilai 3,10. Kondisi lokasi usaha dinilai memiliki kepentingan yang rendah karena kondisi lokasi usaha tidak mempengaruhi secara langsung pada proses produksi. Fu'ad (2015) menyebutkan bahwa lokasi usaha tidak berengaruh langsung apda kegiatan produksi, namun begitu lokasi usaha akan berpengaruh pada kelancan usaha.

Tabel 4. Penilaian rata-rata IPA Kinerja UKM Pengolaham Hasil Perikanan

\begin{tabular}{|c|c|c|c|}
\hline Indikator/Variabel & $\begin{array}{c}\text { Tingkat } \\
\text { Kepentingan } \\
(Y)\end{array}$ & $\begin{array}{c}\text { Tingkat } \\
\text { Kepentingan } \\
\text { (X) }\end{array}$ & $\begin{array}{l}\text { Kinerja } \\
\text { (Persen) }\end{array}$ \\
\hline \multicolumn{4}{|l|}{ Bahan Baku } \\
\hline $\begin{array}{l}\text { 1. Ketersediaan bahan } \\
\text { baku }\end{array}$ & 3,55 & 2,45 & 61,01 \\
\hline 2. Harga bahan baku & 3,20 & 2,80 & 87,50 \\
\hline 3. Kualitas bahan baku & 3,30 & 3,10 & 93,94 \\
\hline \multicolumn{4}{|l|}{ Tenaga Kerja } \\
\hline $\begin{array}{l}\text { 4. Produktivitas tenaga } \\
\text { kerja }\end{array}$ & 3,55 & 2,75 & 79,71 \\
\hline 5. Jumlah tenaga kerja & 3,35 & 3,15 & 94,03 \\
\hline $\begin{array}{l}\text { 6. Keterampilan tenaga } \\
\text { kerja }\end{array}$ & 3,30 & 2,90 & 87,88 \\
\hline \multicolumn{4}{|l|}{ Permodalan } \\
\hline 7. Ketersediaan modal & 3,45 & 3,30 & 95,65 \\
\hline 8. Akses permodalan & 3,30 & 3,10 & 93,94 \\
\hline \multicolumn{4}{|l|}{ Produksi } \\
\hline 9. Kapasitas produksi & 3,30 & 2,80 & 84,85 \\
\hline $\begin{array}{l}\text { 10. kuantitas produk } \\
\text { yang dihasilkan }\end{array}$ & 3,50 & 2,65 & 75,71 \\
\hline $\begin{array}{l}\text { 11. Kualitas produk } \\
\text { yang dihasilkan }\end{array}$ & 3,50 & 3,00 & 85,71 \\
\hline \multicolumn{4}{|l|}{ Pemasaran } \\
\hline 12. Permintaan pasar & 3,55 & 2,71 & 61,34 \\
\hline $\begin{array}{l}\text { 13. Aksesibilitas } \\
\text { distribusi }\end{array}$ & 3,45 & 2,55 & 73,91 \\
\hline 14. Jaringan pemasaran & 3,35 & 2,50 & 74,63 \\
\hline
\end{tabular}


Website: https://jurnal.iainsalatiga.ac.id/index.php/dinamika/index

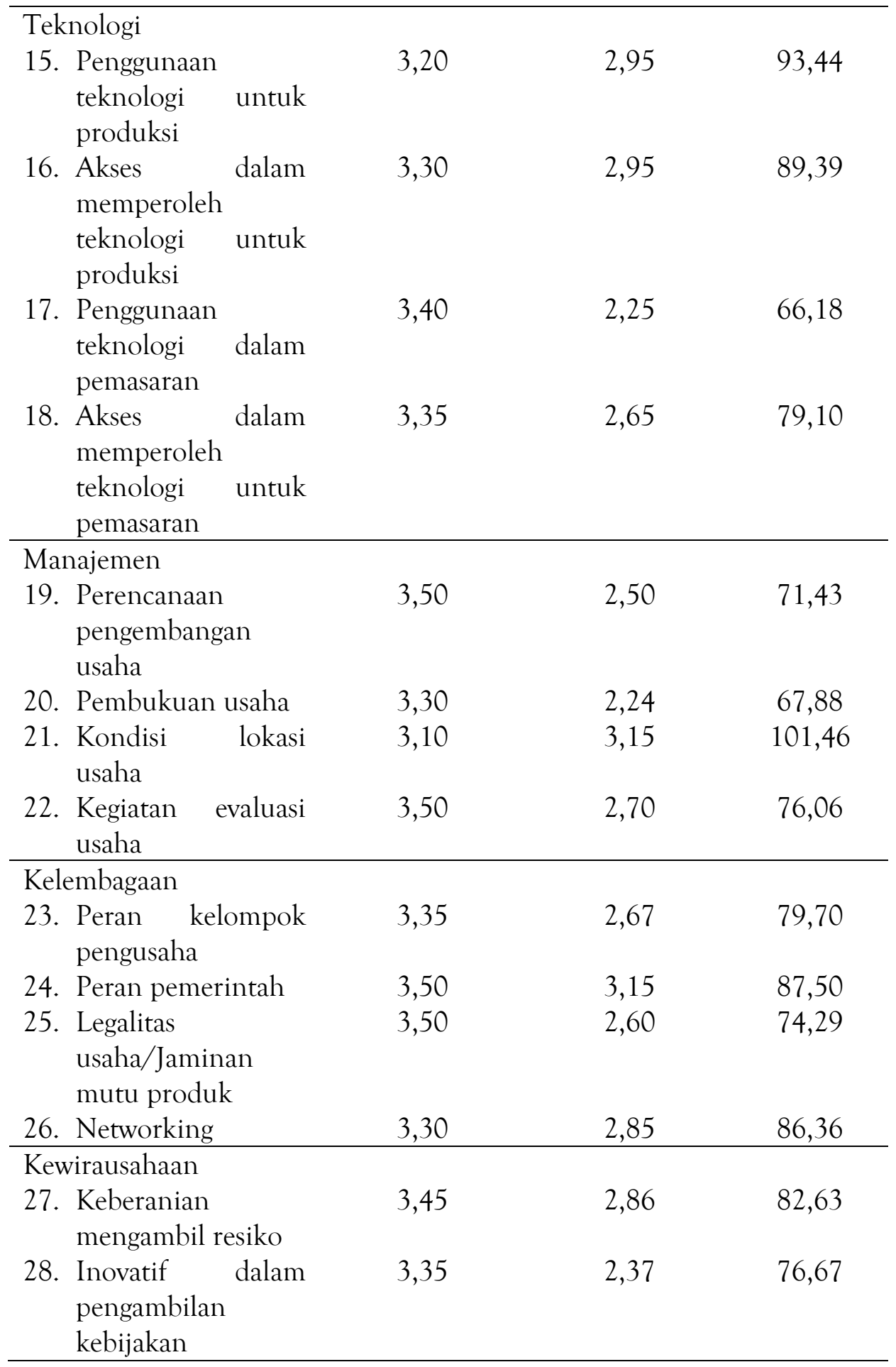

Sumber : data primer yang diolah, 2021

Hasil analisis kinerja menunjukkan terdapat kesenjangan antara tingkat kepentingan dan tingkat kondisi dari variabel-variabel kinerja UKM pengolahan hasil perikanan di Kabupaten Situbondo. Semakin kecil skor 
Jurnal DinamikA

Volume 2 No. 2 (2021)

E-ISSN: $2723-1410$

Website: https://jurnal.iainsalatiga.ac.id/index.php/dinamika/index

kesenjangan dari sebuah variabel maka semakin penting untuk diprioritaskan. Variabel yang memiliki tingkat kinerja terbesar adalah variabel Kondisi lokasi usaha dengan nilai 101,46\%, artinya kondisi saat ini sudah sangat baik dalam mendukung peningkatan kinerja UKM pengolahan hasil perikanan di Kabupaten Situbondo. Sedangkan variabel yang memiliki nilai kinerja terkecil adalah variabel ketersediaan bahan baku dan permintaan pasar dalam UKM pengolahan hasil perikanan di Kabupaten Situbondo dengan nilai $61,01 \%$ dan $61,34 \%$. Kinerja dengan nilai yang rendah menunjukkan variabel tersebut sangat penting untuk diperbaiki.

Menurunnya ketersediaan bahan baku ditengarai disebabkan berkurangnya aktivitas nelayan sebagai penyedia bahan baku dan melambatnya arus distribusi bahan baku yang disebabkan kebijakan pemberlakukan Pemberlakuan Sosial Berskala Besar (PSBB). Menurut Kumala, et.al., (2021), adanya kebijakan Pemberlakuan Sosial Berskala Besar (PSBB) sebagai langkah untuk menghentikan penyebaran Covid-19 juga memperlambat arus distribusi ikan. Melambatnya arus distribusi ikan berdampak berkurangnya aktivitas nelayan dalam kegiatan penangkapan ikan, karena nelayan hawatir hasil tangkapannya tidak terserap oleh pasar. Menurunnya ketersediaan bahan baku berpengaruh pada aktivitas produksi karena bahan baku berfungsi sebagai input produksi. Kelangkaan bahan baku hasil perikanan memang mudah terjadi karena bahan baku hasil perikanan diperoleh melalui pemanfaatan sumber daya alam. Ali. et.al., (2018) menjelaskan bahwa dampak dari terjadinya kelangkaan bahan baku akan memengaruhi keberlangsungan proses produksi. Bahan baku produksi tidak semuanya bersifat mudah serta cepat ditemukan karena bahan utama (hasil perikanan) tersedia melalui pemanfaatan sumber daya alam.

Sementara menurunnya permintaan pasar terhadap produk-produk UKM pengolahan hasil perikanan di Kabupaten Situbondo di tengarai karena pandemi covid-19 yang memberikan dampak pada ekonomi masyarakat. Berdasarkan informasi dari Warta Ekonomi (2020), Pandemi 
Jurnal DinamikA

Volume 2 No. 2 (2021)

E-ISSN: $2723-1410$

Website: https://jurnal.iainsalatiga.ac.id/index.php/dinamika/index

covid-19 telah memberikan dampak ekonomi diantaranya masyarakat kehilangan pekerjaan dan mata pencaharian akibat terkena pemutusahn hubungan kerja (PHK), tempat kerja yang sudah tidak beroperasi, atau hanya tutup dalam waktu tertentu. Kondisi ini tentu berpengaruh terhadap pendapatan yang terus menerus berkurang. Sektor ekonomi keluarga juga mengalami dampak dari terjadinya wabah Covid-19. Menteri Keuangan juga menyatakan bahwa wabah Covid-19 akan memperlambat laju pertumbuhan ekonomi Indonesia. Selain ittu sektor rumah tangga akan mengalami penurunan cukup besar dari sisi konsumsi karena tidak lagi melakukan aktivitas sehingga konsumsi akan menurun cukup tajam dari 3,22\% hingga $1,60 \%$.

\section{c. Strategi Peningkatan Kinerja Usaha Kecil dan Menengah Pengolahan} Hasil Perikanan

Hasil penilaian rata-rata IPA pada Tabel 4, dimasukkan kedalam diagram yang terbagi menjadi 4 kuadran. Pemetaan variabel-variabel tersebut dikakukan berdasarkan rata-rata nilai tingkat kepentingan dan tingat kondisi. Kuadran tersebut disusun atas sumbu X (tingkat kinerja) dan sumbu Y (tingkat kepentingan) yang dibagi berdasarkan rata-rata total dari tingkat kinerja dan tingkat kepentingan. Kuadran IPA menunjukkan posisi setiap variabel-variabel (Gambar 1). 


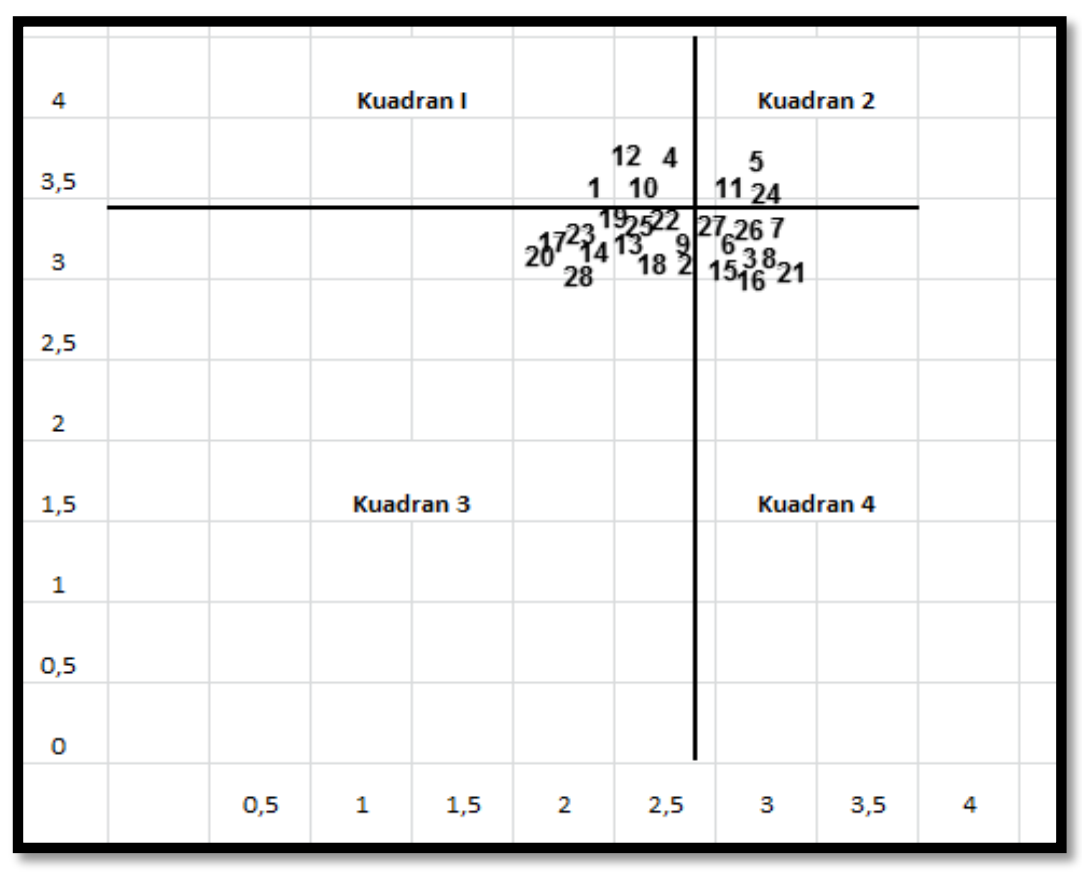

Gambar 1. Diagram IPA Permasalahan Usaha Kecil dan Menengah Pengolahan Hasil Perikanan

(Sumber : data dioalah, 2021)

Strategi peningkatan UKM Pengolahan Hasil Perikanan Kabupaten Situbondo, diturunkan dari hasil analisis IPA, yaitu dengan meningkatkan nilai kondisi saat ini (performance) variabel yang ada pada kuadran I ke kuadran II (Gambar 1). Pada Gambar 1. ditunjukkan bahwa variabel-variabel di dalam kuadran I adalah: Ketersediaan bahan baku (1), Produktivitas tenaga kerja (4), kuantitas produk yang dihasilkan (10) dan Permintaan pasar (12). Pengembangan usaha melalui peningkatan kinerja variabel-variabel tersebut sesuai dengan hasil wawancara dengan UKM pengolahan hasil perikanan di Kabupaten Situbondo.

Berdasarkan hasil wawancara dengan pelaku usaha pengolahan hasil perikanan, kondisi usaha di masa pandemi Covid-19 sangat fluktuatif. Pada saat kinerja produksi baik, permintaan pasar justru turun, pada saat permintaan pasar naik kinerja produksi yang turun. Menurunnya kinerja produksi berdampak pada menurunnya kuantitas hasil produksi. Adapun 
Jurnal DinamikA

Volume 2 No. 2 (2021)

E-ISSN: $2723-1410$

Website: https://jurnal.iainsalatiga.ac.id/index.php/dinamika/index

faktor-faktor yang mempengaruhi menurunnya kinerja produksi adalah kelangkaan bahan baku dan menurunnya produktivitas tenaga kerja. Kelangkaan bahan baku disebabkan distribusi bahan baku yang tidak lancar dan sebagian nelayan tidak melakukan aktivitas penangkapan ikan. Sementara menurunnya produktivitas tenaga kerja dikarenakan sebagian karyawan sakit dan terpapar covid-19, sehingga tidak bisa melakukan aktivitas produksi. Untuk permintaan pasar yang fluktuatif di penagruhi beberapa faktor, misalnya meningkatnya permintaan pasar ditengarai disebabkan terjadinya panic buying yang terjadi diawal-awal pandemi covid-19. Sementara menurunnya permintaan pasar ditengarai disebabkan menurunnya daya beli masyarakat yang mulai terjadi pada 6 bulan kemudian sejak pandemi covid19 diumumkan pada bulan maret 2020.

Pandemi covid-19 belum diketahui kapan berakhir, oleh karena itu diperlakukan strategi agar supaya kinerja usaha pengolahan hasil perikanan bisa bertahan bahkan bisa meningkat. Berdasarkan diagram IPA bahwa permaslaahan UKM pengolahan hasil perikanan bahwa variabel kinerja yang mengalami penurunan adalah kinerja produksi dan kinerja pemasaran. Oleh karena itu pengolah hasil perikanan harus mampu mengendalikan kegiatan produksi dan kegiatan pemasaran dengan menyeimbangkan persediaan dan permintaan. fluktuasi kinerja produksi dan pasar akan berpengaruh pada keseimbangan persediaan dan permintaan. Permintaan dan persediaan yang tidak seimbang akan menurunkan kinerja perusahaan. Sofjan (2013) menjelaskan bahwa persediaan barang berbanding lurus dengan permintaan konsumen, jika permintaan tinggi, maka barang harus tersedia dalam jumlah besar. Oleh karena itu, setiap perusahaan harus bisa memenuhi permintaan konsumen. Menurut Agus (2002), permintaan barang yang banyak dan diluar dugaan sering membuat perusahaan berada dalam posisi yang sulit, Agar menghindari hal itu, perusahaan bisa mengatasinya dengan persediaan gudang yang bisa dikeluarkan sewaktu-waktu. 
Jurnal DinamikA

Volume 2 No. 2 (2021)

E-ISSN: $2723-1410$

Website: https://jurnal.iainsalatiga.ac.id/index.php/dinamika/index

UKM pengolahan hasil perikanan di Kabupaten Situbondo di tengah Pandemi Covid-19 harus memiliki kemampuan manajemen persediaan yang baik. Menurut Basu (2008), manajemen persediaan berfungsi untuk mengatur setiap persediaan yang ada di dalam perusahaan, mulai dari bagaimana cara memperoleh persediaan tersebut, cara penyimpanan, hingga bagaimana persediaan tersebut dimanfaatkan ataupun dikeluarkan. Menururt David (2009), persediaan juga dapat ditingkatkan melalui pelaksanaan produksi yang disertai dengan pengendaliaan produksi. Pengendalian produksi ini bertujuan agar barang jadi atau hasil proses produksi dapat sesuai dengan apa yang diinginkan oleh konsumen baik dalam kualitas maupun kuantitas waktu penyerahaan. Gomes (2000), menambahkan bahwa peningkatan persediaan barang dapat dilakukan melalui peningkatan produksi dan peningkatan produksi dapat di peroleh melalui peningkatan input bahan baku dan permintaan pasar.

\section{KESIMPULAN}

Pandemi Covid-19 telah memberikan implikasi pada menurunnya kinerja UKM pengolahan hasil perikanan di Kabupaten situbondo dengan variabelvariabel yang mempengaruhinya adalah ketersediaan bahan baku (1), produktivitas tenaga kerja (4), kuantitas produk yang dihasilkan (10) dan permintaan pasar (12). Menurunnya kinerja variabel-variabel tersebut berdampak pada ketidak mampuan UKM pengolahan hasil perikanan menjaga keseimbangan antara persediaan dengan. Strategi meningkatkan kinerja UKM pengolahan hasil perikanan pada masa Pnademi Covid-19 adalah menerapkan manajemen persediaan dan permintaan yang baik dengan melakukan pengendalian produksi dan pasar yang juga baik.

\section{DAFTAR PUSTAKA}

Agus. A. (2002). Manajemen Produksi; Pengendalian Produksi. edisi empat. buku dua. BPFE. Yogyakarta 
Jurnal DinamikA

Volume 2 No. 2 (2021)

E-ISSN: 2723-1410

Website: https://jurnal.iainsalatiga.ac.id/index.php/dinamika/index

Algifari. (2016). Mengukur Kualitas Layanan dengan Indeks Kepuasan, Metode Importance Performance Analysis (IPA) dan Metode Kano. Yogyakarta (ID): BPFE Yogyakarta.

Ali. M, E. Kustini Dan Syakhrial. (2018). Penyuluhan Manajemen Pemanfaatan Sumber Daya Alam Untuk Meningkatkan Perekonomian Keluarga Kampung Ciboleger Lebak - Banten. J. Dharma Laksana. 1(1) : 71-80

Amri. A. Dampak Covid-19 Terhadap Umkm Di Indonesia.J BRAND. (2020) Jun $26 ; 2(1): 123-130$

Basu. S. (2008). Manajemen Pemasaran Modern. Liberty Offset. Yogyakarta

Chen, Y. S., Lai, S. B., \& Wen, C. T. (2006). The influence of green innovation performance on corporate advantage in Taiwan. Journal of Business Ethics, 67(4), 331-339.

David. F.R. (2009). Manajemen Startegis, Konsep. Jakarta. Salemba Empat

Fu'ad, N.E. 2015. Pengaruh Pemilihan Lokasi Terhadap Kesuksesan Usaha Berskala Mikro/Kecil Di Komplek Shopping Centre Jepara. Media Ekonomi Dan Manajemen, 30 (1), 62-5

Gomes, F.C. (2000). Manajemen Sumber Daya Manusia. cetakan ke-empat. Andy Offset. Yogyakarta

Kumala. M.T, Vinata.R.T, Setyowati.P.J, Suhartini.T. (2021) Penguatan Kerja Sama Internasional Dalam Mengurangi Dampak Pandemi Covid-19 Terhadap Sektor Perikanan Di Indonesia. J. Hukum. 2021 April $12 ; 50(2): 119-130$ 
Jurnal DinamikA

Volume 2 No. 2 (2021)

E-ISSN: $2723-1410$

Website: https://jurnal.iainsalatiga.ac.id/index.php/dinamika/index

Martha, \& Febriyantoro, M. T. (2019). Analisis Faktor-Faktor Yang Mempengaruhi Perilaku Pembelian Produk Kosmetik Ramah Lingkungan. Jurnal Ecodemica, 3(2), 218-227.

Rosita. R. (2020). Pengaruh Pandemi Covid-19 Terhadap Umkm Di Indonesia. J Lentera Bisnis. 9(2): 109-120

Sofjan. S. (2013). Manajemen Pemasaran: Dasar Konsep dan Strategi. Rajawali Pers. Jakarta

Sutrisno, W. (2014). Green Marketing dan Implikasinya Terhadap Sustainable Development di Era Globalisasi, Kajian Terhadap Strategi Pemasaran yang Berkelanjutan. Business $\mathcal{E}$ Management Jornal, 11(2) : 23-34

Wahidin. L. O, Rudiansyah, Neksidin, Murtini. S. (2020). Dampak Covid-19 Terhadap Ekonomi Perikanan Budidaya Di Kota Lubuklinggau, Sumatera Selatan. J Perikanan Darat dan Pesisir. 1(1): 36-45

Warta Ekonomi. (2020). Menkeu: Pandemi Corona Pukul Konsumsi Rumah Tangga. https://www.wartaekonomi.co.id/read279104/menkeu pandemicorona-pukulkonsumsi-rumah-tangga 